OPEN ACCESS

Edited by:

Marco Leonti,

Università degli Studi di Cagliari, Italy

Reviewed by:

Mohamed Haddad, Institut de Recherche pour le Développement (IRD), France Kannan R. R. Rengasamy, Alagappa University, India

*Correspondence: Lyndy J. McGaw lyndy.mcgaw@up.ac.za

Specialty section: This article was submitted to

Ethnopharmacology,

a section of the journal

Frontiers in Pharmacology

Received: 23 December 2017 Accepted: 18 April 2018 Published: 17 May 2018

Citation:

Abdalla MA and McGaw LJ (2018) Bioprospecting of South African Plants as a Unique Resource for Bioactive Endophytic Microbes. Front. Pharmacol. 9:456. doi: 10.3389/fphar.2018.00456

\section{Bioprospecting of South African Plants as a Unique Resource for Bioactive Endophytic Microbes}

\author{
Muna Ali Abdalla and Lyndy J. McGaw* \\ Phytomedicine Programme, Department of Paraclinical Sciences, Faculty of Veterinary Science, University of Pretoria, \\ Pretoria, South Africa
}

South Africa has a long history and strong belief in traditional herbal medicines. Using ethnobotanical knowledge as a lead, a large number of South African medicinal plants have been discovered to possess a wide spectrum of pharmacological properties. In this review, bioprospecting of endophytes is highlighted by following the advantages of the ethnomedicinal approach together with identifying unique medicinal plants where biological activity may be due to endophytes. This review focuses on the current status of South African medicinal plants to motivate the research community to harness the benefits of ethnobotanical knowledge to investigate the presence of endophytic microbes from the most potent South African medicinal plants. The potential chemical diversity and subsequent putative medicinal value of endophytes is deserving of further research. A timely and comprehensive review of literature on recently isolated endophytes and their metabolites was conducted. Worldwide literature from the last 2 years demonstrating the importance of ethnobotanical knowledge as a useful approach to discover endophytic microbes was documented. Information was obtained from scientific databases such as Pubmed, Scopus, Scirus, Google Scholar, Dictionary of Natural Products, Chemical Abstracts Services, official websites, and scientific databases on ethnomedicines. Primary sources such as books, reports, dissertations, and thesises were accessed where available. Recently published information on isolated endophytes with promising bioactivity and their bioactive natural products worldwide (2015-2017) was summarized. The potential value of South African medicinal plants as sources of endophytes is discussed. The insights provided through this study indicate that medicinal plants in South Africa are highly under-investigated sources of potentially useful endophytic microbes. New approaches may be used by medicinal plant scientists for further exploration of natural products from endophytic fungi and bacteria in southern Africa.

Keywords: South African medicinal plants, secondary metabolites, endophytes, ethnobotanical approach, biological activities

\section{INTRODUCTION}

Malaria, respiratory infections, HIV/AIDS, diarrhoeal diseases, and tuberculosis are leading transmissible and infectious diseases worldwide. Infections are still major human killers in the world, responsible for the mortality of around 50000 people every day (Ahmad and Beg, 2001). An alarming prospect is that three main causes of death reported in pre-antibiotic America were 
tuberculosis, pneumonia, and gastrointestinal infections, and such diseases accounted for $30 \%$ of all deaths (Center for Disease Control and Prevention, 2013). The urgent need for new lead compounds with new modes of action against Gram-positive and Gram-negative bacteria is increasing to combat challenges of resistance against currently used drugs (Fair and Tor, 2014). In this context, the search for bioactive secondary metabolites from different plants and microorganisms as well as discovering new approaches such as microbial biotransformation, microbial co-culture, genome mining, and other molecular tools could be powerful strategies to find novel antibiotic candidates.

South Africa possesses a rich diversity of medicinal plants as well as knowledge of their use. It has been reported that 24 000 taxa exist in the region (Germishuizen and Meyer, 2003). Approximately 3000 species are used as medicines, with about 350 most commonly used in traditional South African herbal medicine (Van Wyk et al., 2009). The unique Cape Floristic region in South Africa demonstrates the greatest extra-tropical concentration of higher plant species in the world. In this area 8600 species are available and $68 \%$ of them were reported to be endemic (Kuete, 2013). It is important to note that the variety of South Africa's climate and altitude is responsible for its diversified flora and fauna. The vegetation regions of South Africa can be divided into four major types; forest and belts of palm in the east, south, and southwest coasts, the temperate grasslands which are located at the eastern portion of the interior plateau, the desert, and semi-desert natural region (Karoo) of the western interior and the final important natural habitat is the bushveld (savanna) which covers the Kalahari and the northeast (Worldmark Encyclopedia of the Nations, 2007). Of the estimated 200 natural orders of plants in the world, over 140 are reported. A huge variety of unique plants is found in the country-overall 200 species of euphorbia in the Cape Province alone, and over 500 species of grass. Wild flowers are one of the natural wonders of the world (including South Africa's national flower, the protea) and these grow in large quantities in the Cape region (Worldmark Encyclopedia of the Nations, 2007).

\section{ENDOPHYTES ARE POTENTIAL SOURCES OF SECONDARY METABOLITES}

An endophyte is a bacterial or fungal species which lives within a plant and has an endosymbiotic relationship with it. All higher plants host a diversity of microbes and they are of growing interest as promising sources of biologically active agents. As a result, some of the metabolites isolated from plant sources trace their origin back to endophytic microbes within the plants, as plants and microorganisms may form intimate associations.

Endophytes can develop within roots, stems, or leaves and consequently colonize the internal plant tissues under the epidermal cell layers without causing any destructive diseases to their host (Strobel, 2003; Stone et al., 2004; Rodriguez et al., 2009; Jumpathong et al., 2010). Plants benefit from endophytic microbes as they synthesize natural products which promote plant growth and stimulate resistance against human pathogens (Bandara et al., 2006). Endophytes enhance plant growth in different ways by production of phytohormones, helping their host plants to tolerate environmental stresses and protecting from pathogens, pests, and herbivores by excreting alkaloids, which are toxic to insects and vertebrates (Schardl, 2001).

Although endophytic microbes have been comprehensively studied, the interaction between different endophytes and their hosts is poorly understood. A combination of factors, which could be environmental, genetic, and phenotypic, create diversiform endophytic microbiomes, but the benefits of these inner microbial communities to their host plants has been severely under-investigated (Compant et al., 2016). More hypothesis-driven studies will provide answers on how these close interactions between plants and endophytes do not cause disease. Investigation of endophytic microbes from medicinal plants is strategic because plants and microorganisms may form close associations and overlap may occur between metabolites from microbes and plants. Bioactive metabolites discovered from endophytes may be related to the independent development of these microorganisms. Alternatively, endophytes may have combined genetic information from their host plants, which stimulates their adaptability and enhances their defense mechanisms against pathogens and insects (Strobel, 2003; Pimentel et al., 2011).

Several antibiotics produced by endophytic actinobacteria isolated from medicinal plants have demonstrated a wide range of bioactivities against bacteria, fungi, and viruses. Additionally, these antibiotics exhibited activity at significantly low concentrations. These findings underline the promising and broad spectrum microbicidal potential of the secondary metabolites obtained from endophytic actinobacteria, mainly of the genus Streptomyces (Golinska et al., 2015). Moreover, numerous species of endophytic fungi have afforded a number of anticancer, antimicrobial, antidiabetic, insecticidal, and immunosuppressive compounds (Schneider et al., 2008). Interesting cyclotetrapeptides were isolated recently from endophytic fungi and bacteria (Abdalla, 2016, 2017).

The strong ethnomedicinal culture in South Africa, the great diversity of its plant species, their varying environments and unique biology and bioactivities serve as a wonderful unexplored source of potentially novel endophytic fungi and bacteria with diverse bioactivities and promising drug candidates. In this report we briefly discuss bioprospecting of South African medicinal plants exhibiting different biological activities to shed more light on the hidden area of endophytes from South African medicinal plants. The study focuses on the importance of ethnobotanical knowledge as an approach to discover endophytic microbes and describes some examples of current screening studies for endophytes and their secondary metabolites.

\section{EXAMPLES OF PREVIOUSLY DISCOVERED IMPORTANT PLANT AND ENDOPHYTE DERIVED METABOLITES AND THEIR MEDICINAL SIGNIFICANCE}

Structures of some important endophyte derived compounds are shown in Figure $\mathbf{1}$ and their sources and mode of action are 


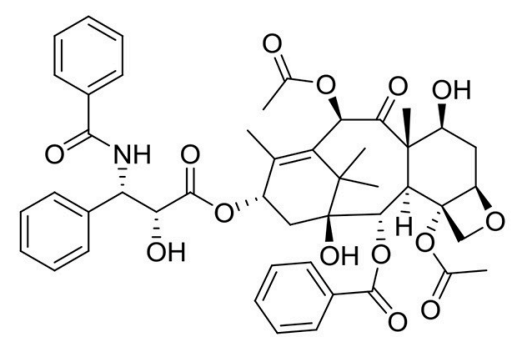

1

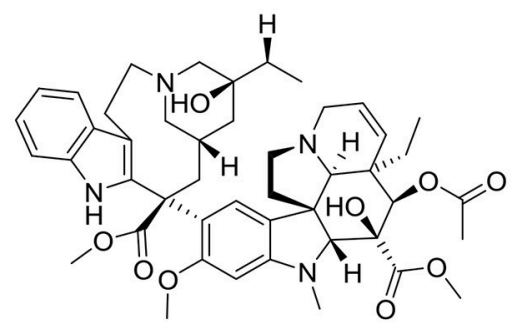

6<smiles>CC[C@@]1(O)C(=O)OCc2c1cc1n(c2=O)Cc2cc3ccccc3nc2-1</smiles>

8<smiles>[R]c1ccc2nccc([C@@H](O)[C@H]3C4CC[C@H]3CN4CC=C)c2c1</smiles><smiles>[R]c1ccc2nccc([C@@H](O)[C@H]3CC[C@H]4CN3C[C@H]4C=C)c2c1</smiles>

$2 \mathrm{R}=\mathrm{OCH}_{3}$ $3 \mathrm{R}=\mathrm{H}$

$4 \mathrm{R}=\mathrm{OCH}_{3}$ $5 \mathrm{R}=\mathrm{H}$
7<smiles>COc1cc([C@H]2c3cc4c(cc3[C@@H](O)[C@@H]3COC(=O)[C@H]23)OCO4)cc(OC)c1OC</smiles>

9

FIGURE 1 | Structures of previously discovered plant and endophyte derived metabolites.

summarized in Table 1. The discovery of the famous anticancer drug paclitaxel (taxol) (1), which is known to be produced by the yew tree Taxus brevifolia, from the endophytic fungus colonizing the related Taxus wallichiana, namely Pestalotiopsis microspora, focused attention on the importance of endophytes. Taxol is certainly the most facinating anticancer therapy for treatment of widespread types of human tumors such as breast, ovarian, prostate, head, neck, and lung cancers (Mekhail and Markman, 2002). Scientists have struggled for a long time to answer a real question: why do endophytic fungi harbored in yew trees make taxol? (Guo et al., 2008). A recent study provided the logical and plausible explanation that an endophytic fungus within the host plant responds to the entering pathogens and deploys specifically to the infection sites in the same way as the circulating immune cells in animals, secreting the antimicrobial compound (Soliman et al., 2015). Thus, endophytes protect their natural habitat within the host plant by secreting taxol in the extracellular spaces in hydrophobic bodies, as a very toxic compound to invading fungi. Another study confirmed the idea that all taxolproducing endophytic fungi have natural resistance to taxol, which possesses a potent antifungal activity against a plethora of fungal pathogens. This can explain the production of taxol by endophytic fungi as a fungicide to keep host plants healthy in a natural habitat (Kusari et al., 2014).

The discovery of the famous Cinchona alkaloids, quinine (2), cinchonidine (3), quinidine (4), and cinchonine (5) from the endophytic filamentous fungus Diaporthe sp. harbored in the medicinal plant Cinchona ledgeriana has gained great interest. The findings demonstrated that Cinchona alkaloids are not only biosynthesized in Cinchona plant cells, but also in endophyte cells (Maehara et al., 2011). Cinchona alkaloids played an important role in human society as antimalarial drugs for more than 400 years (Song, 2009). Quinidine and cinchonine were the most active antimalarial drugs followed by quinine and cinchonidine. Although quinidine has been reported to exhibit 2 to 3 -fold the antimalarial potency of quinine in both chloroquine sensitive and chloroquine-resistant strains of Plasmodium falciparum (Warhurst et al., 2003), it is not recommended for use as antimalarial therapy because of its cardiac activity. Accordingly quinine is approved as the most effective antimalarial drug.

The anticancer drugs vinblastine (6) and vincristine (7) have been obtained from the endophytic fungus Fusarium oxysporum which resides in a symbiotic relationship inside the medicinal plant Catharanthus roseus (Kumar et al., 2013). Vinblastine 


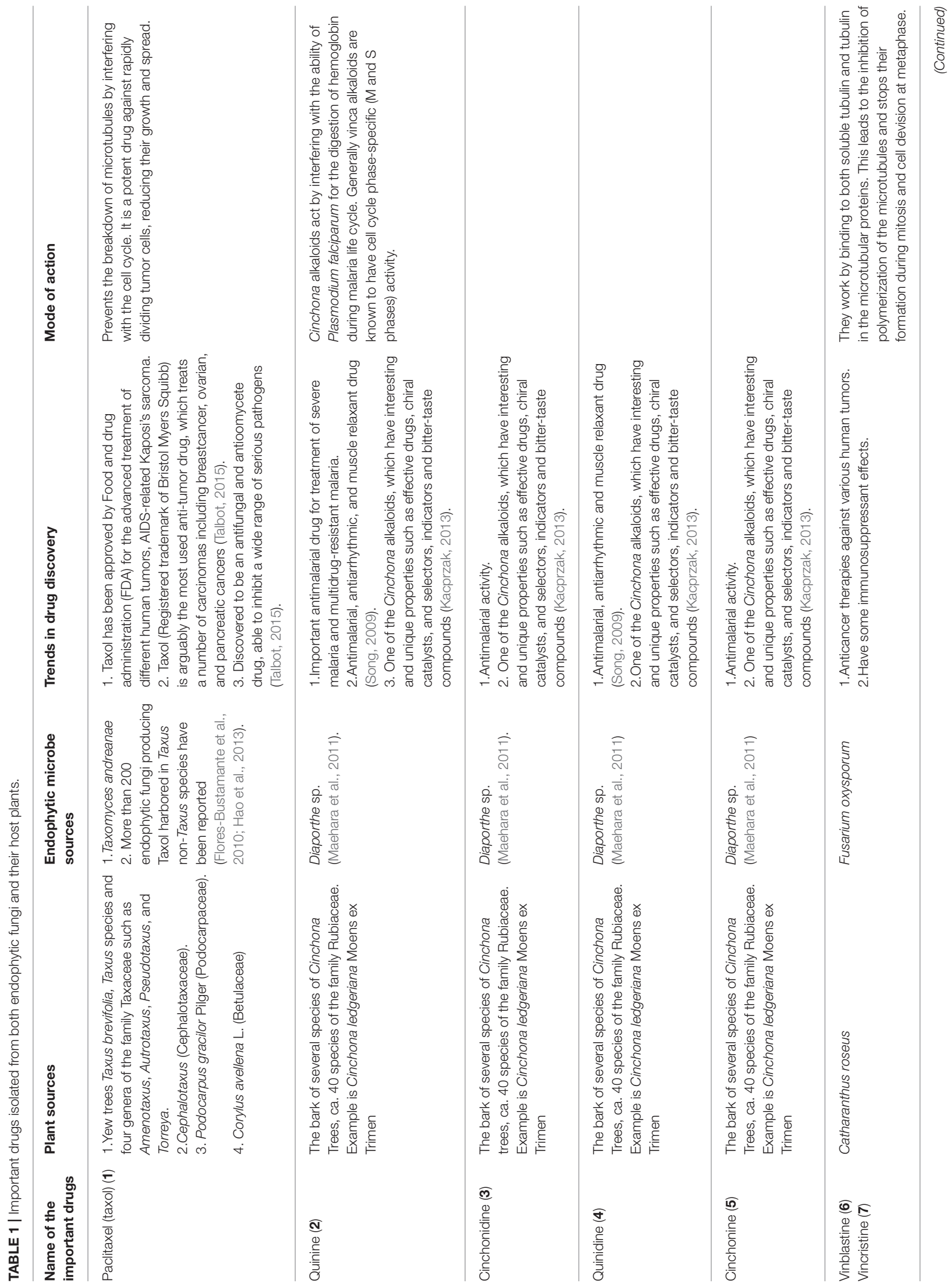


(6) and vincristine (7) are important components of vinca alkaloids in addition to vinorelbine and vindesine (Moudi et al., 2013). Vinca alkaloids are classified as the second most important class of anticancer agents and are used as original cancer therapies. The potent antineoplastic drug camptothecin (8) which is known to be produced by the medicinal plant Camptotheca acuminata, was also isolated from the endophytic fungus Fusarium solani obtained from the same plant (Kusari et al., 2009). Numerous previous publications have reported the pharmacological potential of camptothecin (8), which has therapeutic properties against AIDS and malaria in addition to uterine, colon, cervical, and ovarian cancer (Li et al., 2006).

Podophyllotoxin (9), a precursor of clinically important anticancer drugs, is not only obtained from the medicinal plant Podophyllum (Sinopodophyllum) peltatum but has also been discovered from the endophytic fungus Phialocephala fortinii isolated from the same plant (Eyberger et al., 2006). The isolation of podophyllotoxin (9) from the endophytic fungal culture can be optimized to obtain good quantities of the compound for further studies in drug development and clinical trials. The discovery of an endophytic fungus as a source of compound 9 will reduce the need to harvest the source plants.

From the above mentioned examples it can be assumed that endophytic fungi that are symbiotically harbored in host plants may have the capability to biosynthesize exactly the same secondary metabolites as their host plants. This could be due to the intergeneric genetic exchange that can be possible between the host plants and their endophytic fungi. As a result of continuous co-evolution and a symbiotic relationship with their host plants, it can be assumed that the endophytic fungi were adapted and familiarized to their special habitat. This may have led to gradual genetic variation, which allowed the endophytic fungi to take up some plant DNA segments into their own genomes. Morover endophytes can insert their own DNA segments into the host plant genomes. This can be a logical explanation of why endophytes have the ability to biosynthesize some secondary metabolites originating from their host plants (Gunatilaka, 2006; Zhang et al., 2006). The typical and historical example is the production of gibberellins from both fungi and plants (Choi et al., 2005).

\section{WHAT MAKES SOUTH AFRICAN MEDICINAL PLANTS A UNIQUE SOURCE TO EXPLORE THEIR ENDOPHYTES? Interesting Commericialized South African Plants in the Global Markets}

The indigenous medicinal plants of South Africa have been widely documented and investigated for their unique biology and chemical diversity. The Flora Capensis (a colonial flora) of South Africa was reported by Harvey and Sonder $(1860,1862,1864)$ including important and ethnomedicinal uses of several species. Moreover, the exceptionally diverse and interesting South African flora has been known in the global market as the origin of many innovative products. Fifteen of the most important South African species were 
extensively discussed for their special commercial interest in the global market (Van Wyk, 2011). These plants are Xysmalobium undulatum, Agathosma betulina, Aloe ferox, Aspalathus linearis, Artemisia afra, Cyclopia genistoides, Hoodia gordonii, Harpagophytum procumbens, Hypoxis hemerocallidea, Lippia javanica, Mesembryanthemum tortuosum, Warburgia salutaris, Pelargonium sidoides, Siphonochilus aethiopicus, and Sutherlandia frutescens (Van Wyk, 2011). These plants were produced as standardized products and are available in the international markets as tablets, capsules, teas, and tinctures (Van Wyk, 2011). Table 2 summarizes some commercially interesting South African plants and their importance.

\section{Biological Importance of South African Plants}

The efficacy and potency of South African medicinal plants has been studied in terms of both human and animal health. Extensive research has been conducted in different fields of interest in South Africa such as ethnomedicine, ethnoveterinary medicine, and phytomedicine to screen a wide variety of South African indigenous plants. Thus, very interesting biological activities of these plants have been discovered, such as antimicrobial efficacy, against a diverse range of Gram-positive and Gram-negative bacteria (Van Vuuren, 2008; Nyila et al., 2012; Okem et al., 2012; Mabona et al., 2013; Sharma and Lall, 2014; Aro et al., 2015; Elisha et al., 2016; Kabongo-Kayoka et al., 2016; Ramadwa et al., 2017) in addition to a large spectrum of fungi (Adamu et al., 2012; Otang et al., 2012). Moreover, anticancer (Sharma and Lall, 2014; Saeed et al., 2016), antioxidant (Saeed et al., 2012; Sharma and Lall, 2014; Dzoyem and Eloff, 2015), antiinflammatory (Dzoyem and Eloff, 2015), anthelmintic (Aremu et al., 2010; Maphosa et al., 2010; Maphosa and Masika, 2012; Okem et al., 2012), antimalarial (Clarkson et al., 2004), antiviral (Bagla et al., 2012; Mehrbod et al., 2018), antidiabetic (Oyedemi et al., 2009; Kibiti, 2016), anti-HIV (Kamng'ona et al., 2011; Hurinanthan, 2013; Mthethwa et al., 2014) activities have been reported. Comprehensive reviews and surveys have discussed the potential of South African plants to treat inflammatory conditions (Iwalewa et al., 2007), diarrhea (Lin et al., 2002; Mathabe et al., 2006; Fawole et al., 2009; Bisi-Johnson et al., 2010; Semenya and Maroyi, 2012; Van Vuuren et al., 2015; Motlhatlego et al., 2018) and TB-related symptoms (McGaw et al., 2008).

In summary the unique diversity of South African plant species, in addition to their promising and potential bioactivities, is emphasized to alert researchers to the need to explore these plants as viable sources of endophytes for the production of potential drug candidates.

\section{ISOLATION AND IDENTIFICATION OF ENDOPHYTES}

Acquiring endophytic fungi and bacteria with broad bioactivities requires selection criteria of the plant species. They should have ethnomedicinal history, unique biology, endemism, and special habitats (Yu et al., 2010). It is important to note that the plant should look apparently healthy, and young plant tissue is better than older material, especially in the case of isolation of endophytic fungi where slow-growing fungi are difficult to isolate (Strobel, 2003; Strobel and Daisy, 2003). Endophytes can be obtained from different plant parts such as seeds, leaves, and stems. Surface sterilization is a critical prerequisite in the most commonly used method for isolation of endophytes. This step is very important to eliminate possible contaminants, foreign material and fungal epiphytes and molds from plant tissues and encourage the growth of the internal microorganisms. Cutting plant material into many small pieces will increase the efficiency of sterilization and the isolation. Sterilization steps will be followed by the isolation of the endophytic fungi and bacteria on specific synthetic growth medium. Surface sterilization is a procedure in which plant material is treated with a surfactant such as ethanol (70-95\%) followed by a strong surface sterilant for a short period; the household chlorine bleach $(\mathrm{NaOCl})$ is usually used in concentrations of $2-10 \%$ after being diluted in water. The plant material is washed again with ethanol followed by several rinses in sterile water to remove residual sterilant. Ultrasonic cleaning equipment is an efficient surface sterilization protocol. A wide range of routine bacterial and mycological media are used for growth of bacteria and fungi, as well as isolation and subculturing for identification (Stone et al., 2004; Gagne-Bourque, 2011). For bacterial endophytes many media have been reported, such as Nutrient Agar (NA), Viande-Levure (Pavlo et al., 2011), or Rice extract Modified Rennie (RMR). For endophytic fungi malt extract agar medium is commonly used, alone or in combination with yeast extract (Stone et al., 2004).

Optimal incubation conditions for fungi and bacteria are required to facilitate their primary growth and further subculturing steps. Based on their morphological and staining properties the successfully isolated endophytes are maintained as pure strains by several steps of sub-culturing processes. The purified bacteria and fungi are identified by means of morphological characteristics such as conidiogenesis and spore morphology in the case of fungi and texture opacity, color, form, and Gram-staining in the case of bacteria. Biochemical and molecular characterizations are additional techniques for endophyte identification. PCR amplification which requires universal primers targeting different conserved sequences of the rRNA genes and then DNA sequencing of the internal transcribed spacer (ITS) region is the most commonly used method for identification of a broad range of fungi to the species level (Schoch et al., 2012). For bacterial strains the universal method involves the PCR product of the 16S rRNA genes after designing suitable primers. A PCR product is sequenced and aligned and homology comparison is carried out using Genbank and other databases for identification. The procedure of isolation and characterization of endophytes is described in Figure 2.

\section{WHY IT IS SO CHALLENGING TO CULTIVATE ENDOPHYTIC MICROBES?}

Micoorganisms such as epiphytes can be found on the plant surface, and also within plant tissues as endophytes. Numerous endophytic fungi and bacteria have shown beneficial effects 


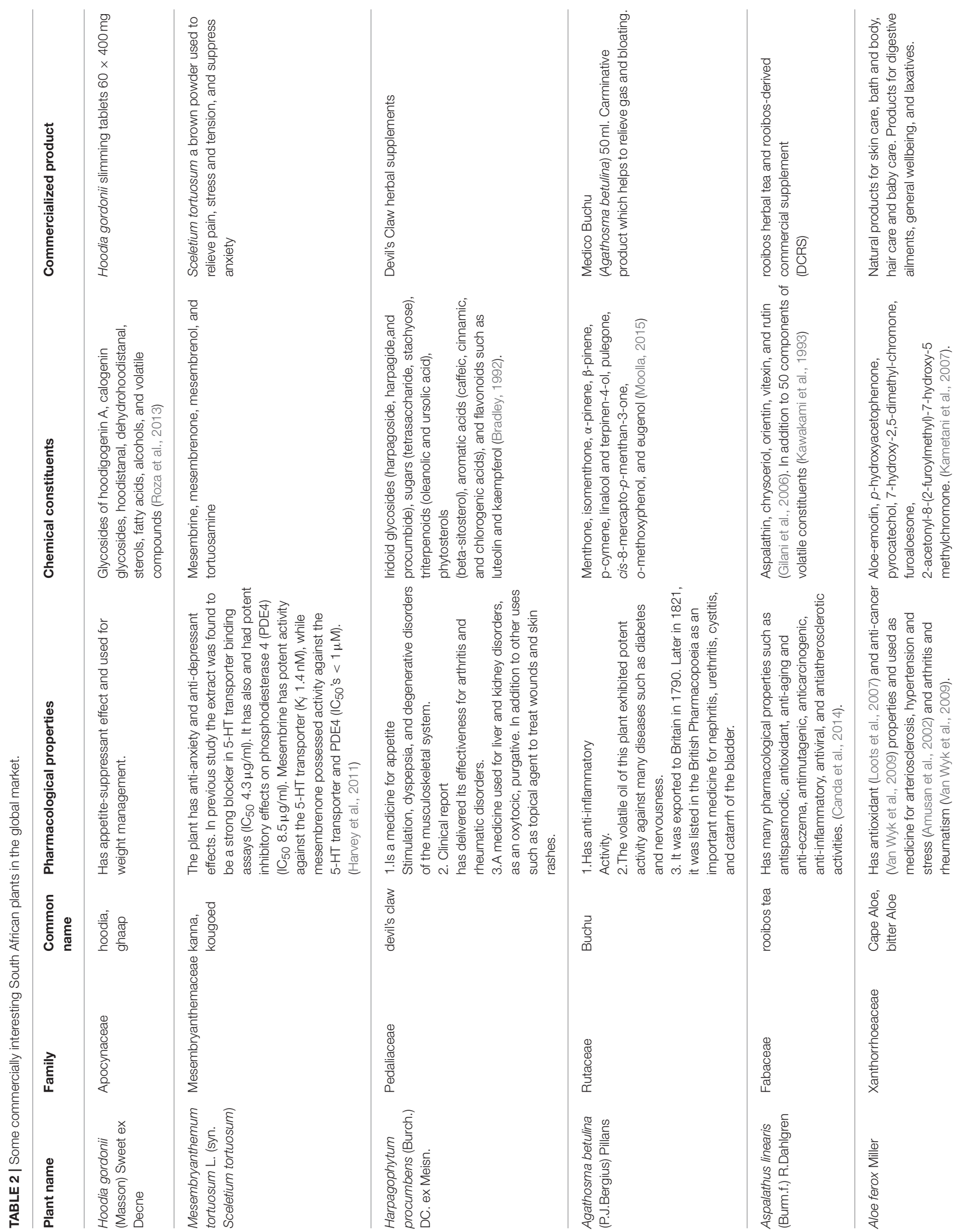




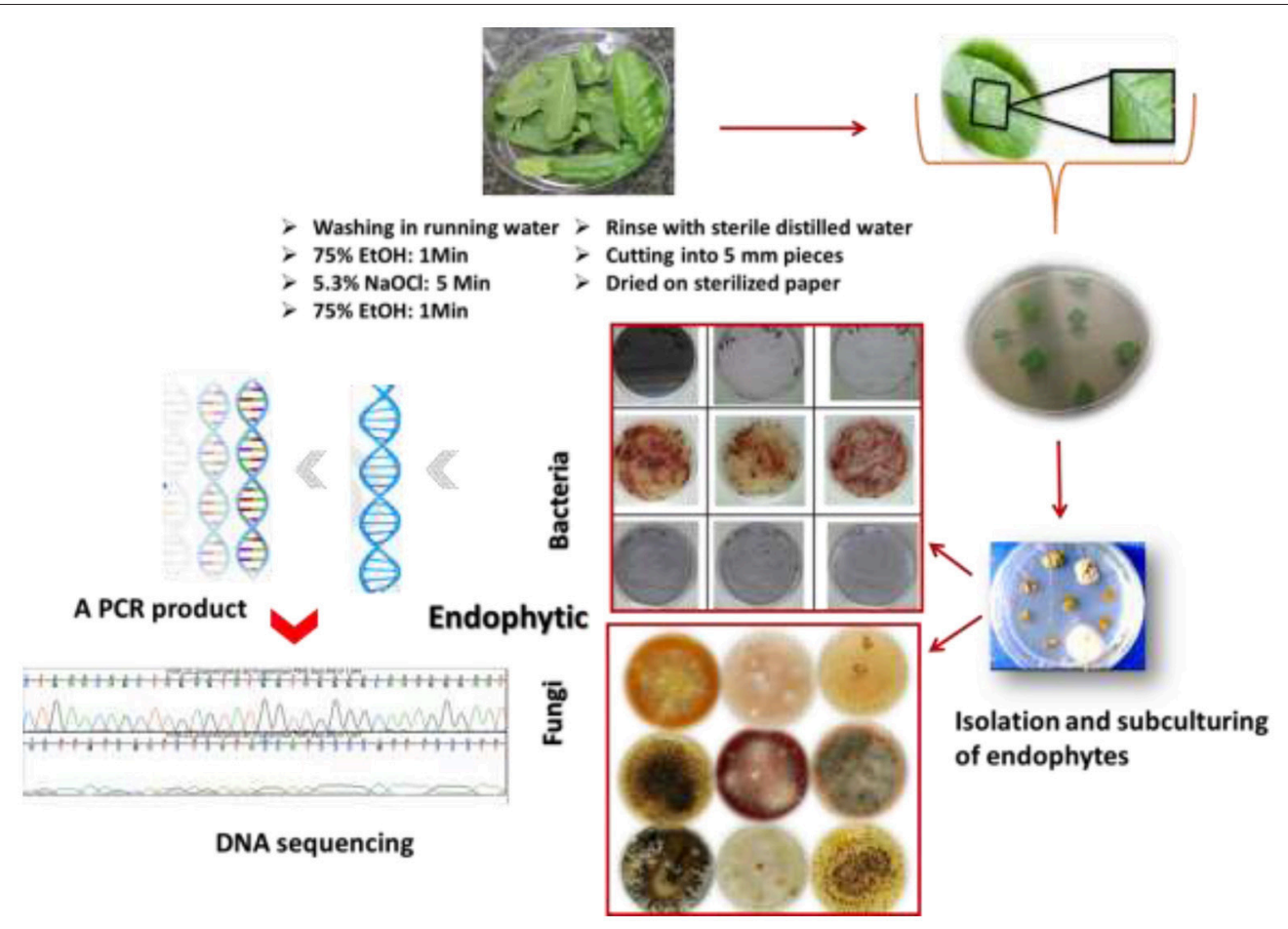

FIGURE 2 | Overview of the procedure of isolation and identification of endophytic strains.

on host plants, and this can be utilized in biotechnological applications. Additional research indicates that only $0.001-$ $1 \%$ of endophytic bacteria are cultivable. Many isolated endophytic bacteria have reduced growth capacity (Alain and Querellou, 2009), are unculturable and need culture-independent techniques for detection and characterization (Liaqat and Eltem, 2016). In general, the majority of microorganisms are "uncultured" under laboratory controlled conditions (Lewis et al., 2010).

Difficulties in culturing many isolated endophytes may be attributed at least partly to residual plant metabolites, which are present during the isolation step but are not available during recultivation of the endophytes. It has been reported that crushed plant material contains molecules which are not present in the growth media, and such substances contribute to the growth of endophytic microbes (Eevers et al., 2015). Two types of endophytes can be found, namely obligate (Croes et al., 2013) and facultative endophytic microbes (Kamnev et al., 2005). Obligate endophytic strains are the hardest to grow due to their specific requirements. Developing new ways, approaches and mechanisms to cultivate unculturable endophytic and non-endophytic microorganisms is a top research priority in the field of microbial natural products. In this context it is very important to understand why unculturable microorganisms are uncultivated (Hurst, 2005). Strategies such as adopting single cell and high-throughput culturing procedures (Connon and Giovannoni, 2002; Nichols et al., 2008) better mimicking the natural milieu of the microrganisms (Bruns et al., 2002) and increasing the time of incubation and decreasing the concentration of nutrients have been used previously (Davis et al., 2005). The mixed fermentation or co-culture strategy has led to the discovery of the first class of growth factors for uncultured bacteria such as siderophores, and a previous study found that siderophores from neighboring microorganisms within the biofilm allowed uncultured bacteria to grow in a sand biofilm (Lewis et al., 2010). The technology of a diffusion chamber was used by NovoBiotic company (Cambridge, MA, USA) to induce the growth of uncultured actinomycetes (Lewis et al., 2010).

\section{ETHNOBOTANICAL KNOWLEDGE IS A SCIENTIFIC APPROACH TO DISCOVER ENDOPHYTIC MICROORGANISMS}

The rich biodiversity of South African medicinal and indigenous plants together with the strong beliefs and practices of diverse ethnic groups (Van Wyk et al., 2009) have encouraged the South African research community to evaluate local indigenous plants for several biological activities such as antimicrobial, anticancer, anti-inflammatory, antioxidant, anti-HIV, and antimalarial properties. It is very important to mention that one of the most fascinating approaches used to discover promising endophytic strains is to follow ethnobotanical knowledge, where the ideas and experience of native people who usually rely on plants and plant materials as medicines and have a very long history must be considered (Abdalla and Matasyoh, 2014). 


\section{Bioprospecting of Chinese Medicinal Plants as a Source of Endophytes}

The Chinese scientific research community recently began screening their medicinal plants with a focus on endophytic fungi and bacteria, their isolation, and bioactivities as new sources of natural lead compounds. Many examples have been reported, such as the endophytic streptomycetes, which were obtained from medicinal plants of the rainforest in Yunnan province, China, and were shown to have remarkable antitumour and antimicrobial activities (Li et al., 2008). One of the most interesting examples supporting the idea that endophytic microorganisms may be responsible for the medicinal properties of the particular plant species under study is the potent antimicrobial activity of the endophytic fungus Fusarium proliferatum which was isolated from the traditional Chinese medicinal plant Celastrus angulatus (Ji et al., 2005). In a screening study to investigate the potential of endophytes to produce bioactive secondary metabolites, the total DNA extract of endophytes isolated from 30 traditional Chinese herbs was used to screen PKS and NRPS gene clusters, and many of the endophytes under study were found to have the potential to produce bioactive secondary metabolites (Miller et al., 2012). The leaf of the Chinese endemic plant Maytenus hookeri, which is only found in the Yunnan area, afforded the endophytic fungus Chaetomium globosum, which delivered the anti-tuberculosis agent chaetoglobosin B (Ni et al., 2008).

\section{Discovery of the Peptides Munumbicins From Endophytic Streptomycetes in Australia}

The ethnomedicinal approach afforded the peptides munumbicins, which were obtained from the endophytic Streptomyces NRRL 3052 isolated from the snakevine, Kennedia nigriscans. The latter plant was explored several years ago by a tribal leader, Reggie Munumbie, as a medicinal remedy in Aboriginal Australian culture to manage open, bleeding wounds to preclude sepsis. Currently, at least 39 different Streptomyces spp. have been discovered from several snakevine plants collected in different areas in the Northern Territory, Australia (Kunoh, 2002; Castillo et al., 2005). Moreover, most of the snakevine endophytic streptomycetes exhibit antimicrobial activity (Castillo et al., 2005). These findings support the premise that the world's rainforests are a great producer of endophytic streptomycetes.

\section{Plants of Latin America as a Potential Source of Endophytes: Brazil and Mexico as Examples}

Around 20\% or the estimated 300000 plant species in the world exist in Brazil. Despite the diversity of Brazilian plants, studies on endophytic microbes from Brazil remain sparse. Several research groups are exploring endophytes from plants of not yet fully explored areas such as mangrove, Amazon, and Atlantic rain forests (Azevedo, 2014). It was reported that some endophytic fungi producing antimicrobial compounds were discovered from Brazilian mangroves (Sebastianes et al., 2012). Endophytes from
Brazilian plants growing in the Amazon region and Atlantic forest have also been studied (Souza et al., 2004). A recent study explored ten actinomycetes from the medicinal plant Vochysia divergens found in the Pantanal sul-mato-grossense, an interesting unexplored area in Brazil. The Pantanal is well-known for its biological diversity in terms of its fauna and flora (Alho, 2008). This study discovered rare actinomycetes, which were never before reported as endophytes. The endophytic strains showed antimicrobial potential and were largely resistant to the antibiotics oxacillin and nalidixic acid (Gos et al., 2017). Among isolated strains the extract of the endophytic LGMB491 which is closely related to Aeromicrobium ponti exhibited remarkable bioactivity against methicillin-resistant Staphylococcus aureus (MRSA) with MIC of $0.04 \mathrm{mg} / \mathrm{ml}$. Interestingly the strain delivered antibacterial compounds such as 1-acetyl-b-carboline, indole-3-carbaldehyde, 3-(hydroxyacetyl)-indole, brevianamide F and cyclo-(L-Pro-L-Phe) (Gos et al., 2017).

In Mexico the medicinal plant Dendropanax arboreus (L.) Decne. \& Planch, which is known as Angelica tree and exsists in Mexico and South America, has ethnomedicinal uses in Mexico and Latin America such as managing fever, snakebites, and intestinal parasites (Bourdy et al., 2000). The anticancer compound falcarindiol, which showed potential activity against different types of cancer in animal models, was isolated from this plant (Setzer et al., 2000). Recently 45 endophytic fungi were obtained from $D$. arboreus. The crude extracts of the isolated endophytes such as Corynespora, Endomelanconiopsis, and Thozetella exhibited antifungal and antibacterial activity (Ramos-Garza et al., 2015). Moreover, a recent study in Mexico investigated the association of bacteria, archaea and fungi with the native cacti species Myrtillocactus geometrizans and Opuntia robusta, demonstrating the potential diversity of endophytes (Fonseca-García et al., 2016).

\section{CURRENT SCREENING STUDIES FOR ENDOPHYTES AND THEIR METABOLITES WORLDWIDE}

Table 3 provides a summary of global endophyte studies published in the last 2 years. Glycyrrhiza glabra L. is a famous medicinal plant used in traditional medicine worldwide for its ethnopharmacological characteristics to treat many ailments (Hosseinzadeh and Nassiri-Asl, 2015). In clinical studies and scientific research G. glabra and other species of the genus Glycyrrhiza exhibited potent pharmacological properties such as antimicrobial, antiinflammatory, antioxidant, antiviral, antidiabetic, anti-asthma, and anticancer activities in addition to immunomodulatory, neuroprotective, hepatoprotective, gastroprotective, and cardioprotective applications (Hosseinzadeh and NassiriAsl, 2015). An endophytic fungus, Phoma sp. GG1F1 was isolated from G. glabra and its extract demonstrated significant antimicrobial activity. Two thiodiketopiperazines 8 and 9 (Figure 3) were obtained from the extract of the endophytic fungus Phoma sp. GG1F1 culture. Compounds $\mathbf{8}$ and $\mathbf{9}$ displayed very interesting bioactivities, as they decreased the growth of 


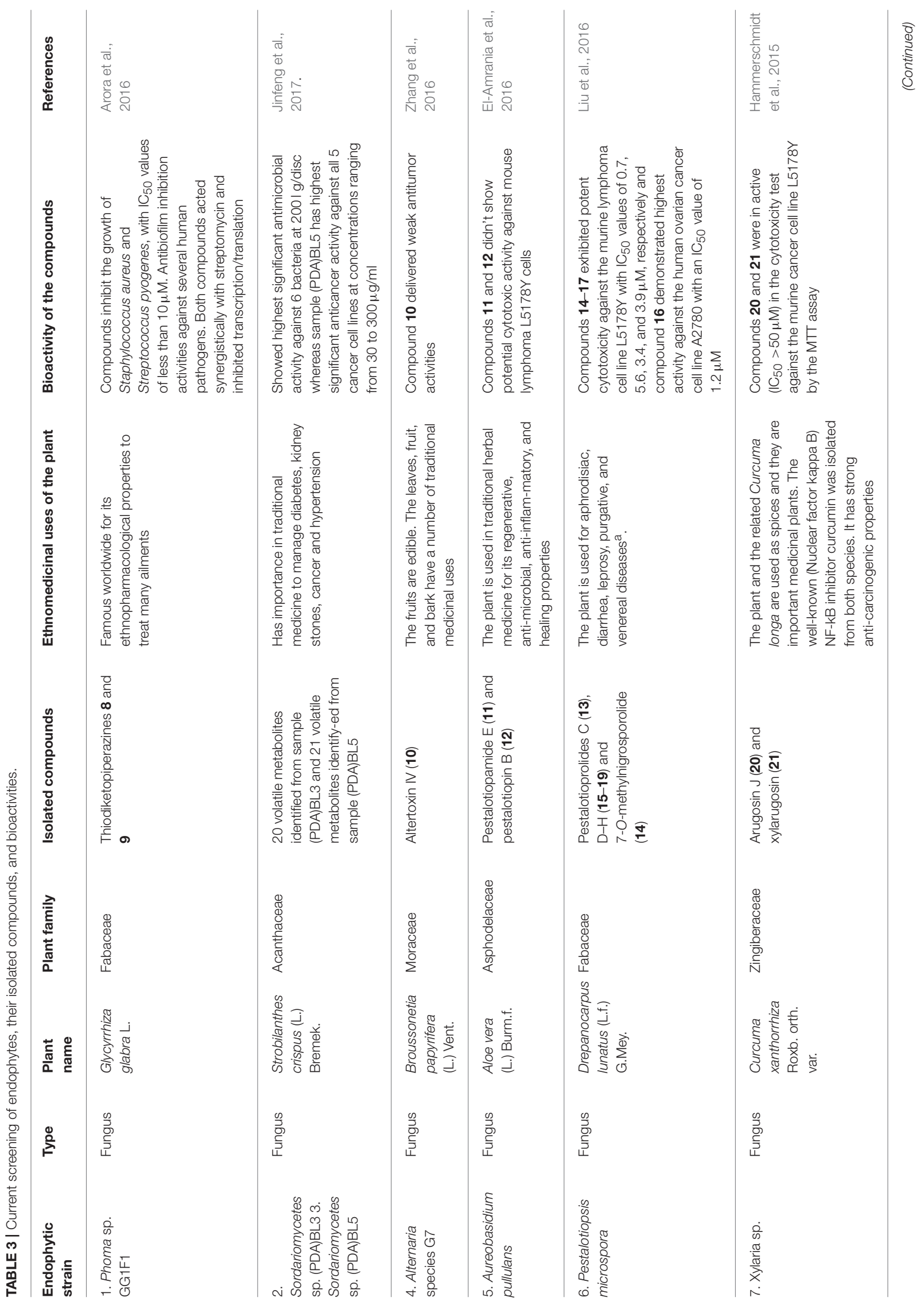




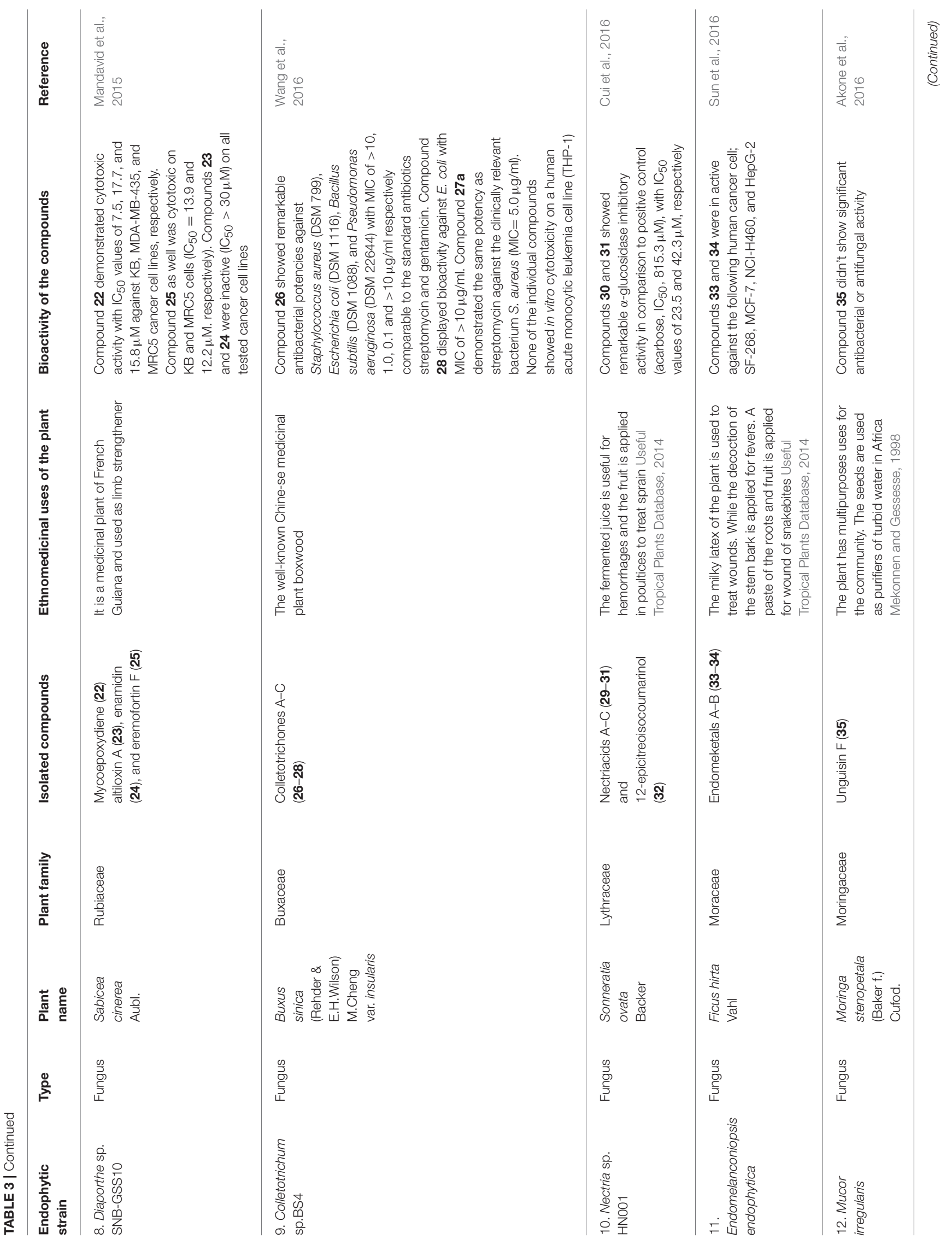




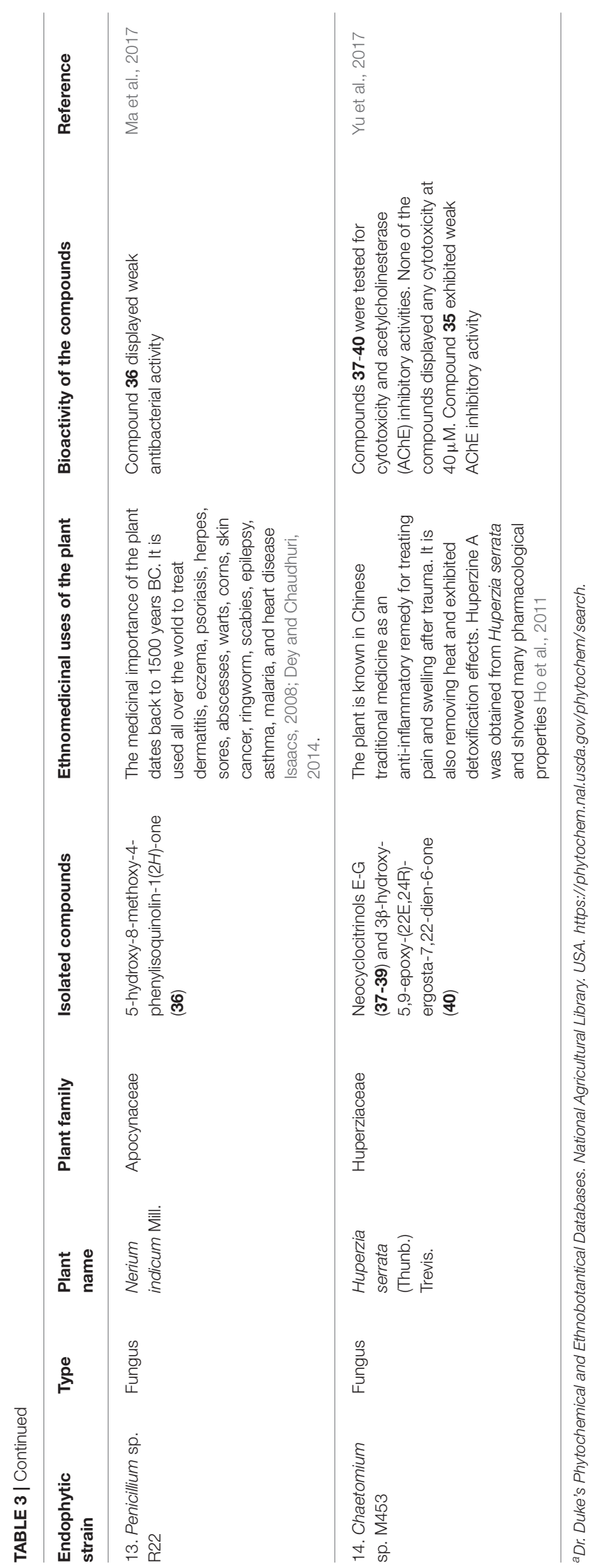

numerous bacterial pathogens such as Staphylococcus aureus and Streptococcus pyogenes, with $\mathrm{IC}_{50}$ values of less than $10 \mu \mathrm{M}$. Moreover, compounds $\mathbf{8}$ and $\mathbf{9}$ inhibited in a promising manner the biofilm formation in both pathogens. They afforded potent bactericidal activity in in vitro time kill kinetics. Compounds $\mathbf{8}$ and $\mathbf{9}$ are capable of acting synergistically with streptomycin and causing different effects in combination with ciprofloxacin and ampicillin. Additionally they are able to inhibit bacterial transcription/translation in vitro, and staphyloxanthin production in S. aureus (Arora et al., 2016).

Strobilanthes crispus is a medicinal plant used in traditional medicine to treat diabetes, kidney stones, cancer, and hypertension and it has antimicrobial activities (Jinfeng et al., 2017). Two fungal endophytes closely related to Sordariomycetes sp. were obtained from S. crispus. Both endophytic fungi, named Sordariomycetes sp. (PDA)BL3 and Sordariomycetes sp. (PDA)BL5 exhibited potent antimicrobial activity against 6 bacterial strains at $200 \mu \mathrm{g} /$ disc and high anticancer activity against 5 cancer cell lines at concentrations ranging from 30 to $300 \mu \mathrm{g} / \mathrm{ml}$, respectively. Twenty volatile metabolites were obtained from the endophytic fungus Sordariomycetes sp. (PDA)BL3 and 21 volatile metabolites were noted from the second endophytic fungus Sordariomycetes sp. (PDA)BL5 using gas chromatography coupled with mass spectrometry (GC-MS). The study recommended that further identification of the compounds responsible for the interesting antimicrobial and anticancer activities of both endophytic fungi should be done.

Altertoxin IV (10) was recently discovered from the ethyl acetate extract of a culture of the endophytic fungus Alternaria species G7 in Broussonetia papyrifera along with other previously known cytotoxic compounds. Altertoxin IV (10), a new member of the perylenequinone derivatives, exhibited weak antitumor activities (Zhang et al., 2016). An amide pestalotiopamide E (11) and its corresponding acid pestalotiopin B (12) were isolated from the mycelial extract of the endophytic fungus Aureobasidium pullulans cultured from leaves of Aloe vera (Asphodelaceae) collected from Marrakesh (Morocco) (ElAmrania et al., 2016).

Recently, seven new 14-membered macrolides, pestalotioprolides C (13), D-H (15-19) and 7-Omethylnigrosporolide (14) were isolated from the mangrovederived endophytic fungus Pestalotiopsis microspora obtained from fresh fruits of the mangrove plant Drepanocarpus lunatus (Fabaceae) collected in Cameroon (Liu et al., 2016). Compounds 14-17 showed significant cytotoxicity against the murine lymphoma cell line $\mathrm{L} 5178 \mathrm{Y}$ with $\mathrm{IC}_{50}$ values of $0.7,5.6,3.4$, and $3.9 \mu \mathrm{M}$ respectively, while compound $\mathbf{1 6}$ showed potent activity against the human ovarian cancer cell line A2780 with an $\mathrm{IC}_{50}$ value of $1.2 \mu \mathrm{M}$ (Liu et al., 2016).

The endophytic fungus Xylaria sp. isolated from the medicinal plant Curcuma xanthorrhiza, collected on the island of Timor, Indonesia afforded two new compounds, arugosin $\mathrm{J}(\mathbf{2 0})$ and xylarugosin (21). The two metabolites 20 and 21 were inactive $\left(\mathrm{IC}_{50}>50 \mu \mathrm{M}\right)$ when tested for cytotoxicity against the murine cancer cell line L5178Y by the MTT assay (Hammerschmidt et al., 2015). The Diaporthe genus is the sexual form of Phomopsis, and these are important endophytic fungi obtained from tropical and 


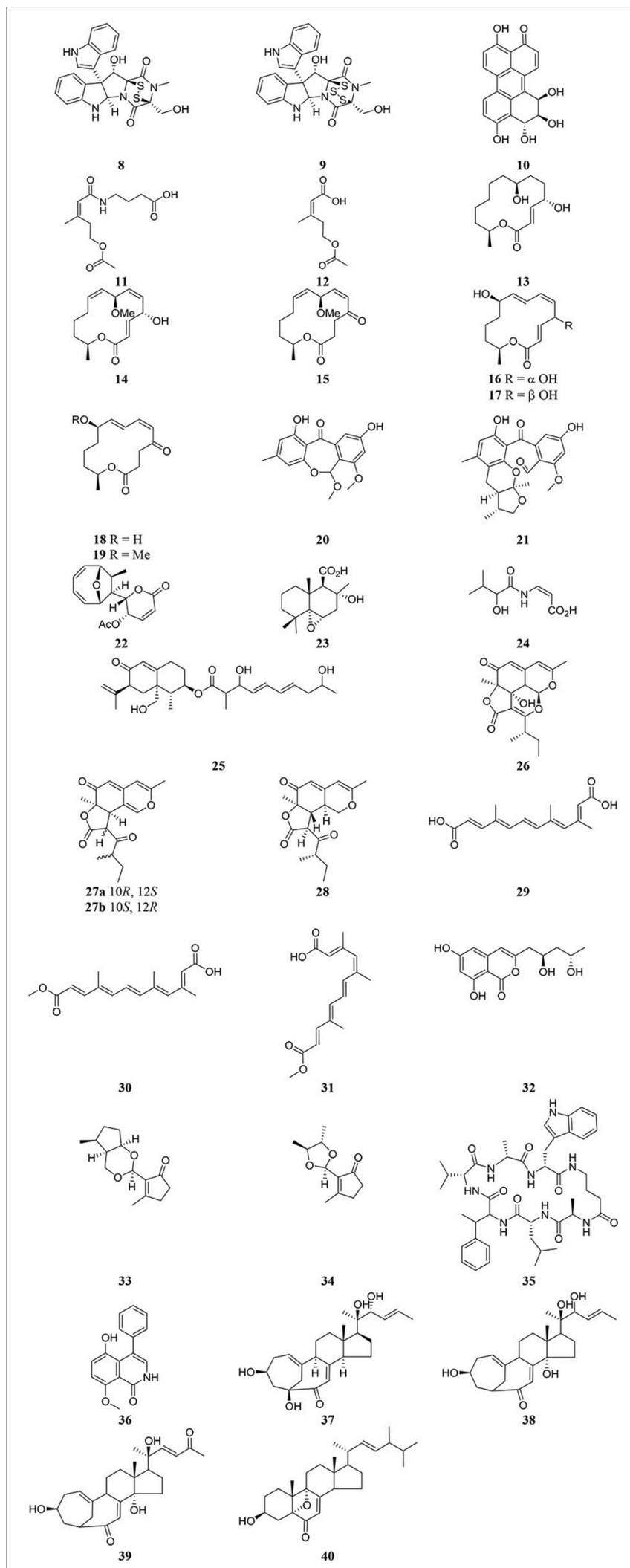

FIGURE 3 | Structures of secondary metabolites isolated recently from endophytic microorganisms. temperate woody plants. They have a potential role in protecting plants from fungal infection (Mandavid et al., 2015).

The endophytic fungus Diaporthe sp. SNB-GSS10 which was isolated from a medicinal plant Sabicea cinerea delivered four bioactive componds mycoepoxydiene (22) altiloxin A (23), enamidin (24), and eremofortin F (25) (Mandavid et al., 2015). Compound 22 displayed cytotoxic activity with $\mathrm{IC}_{50}$ values of 7.5, 17.7, and $15.8 \mu \mathrm{M}$ against KB, MDA-MB-435, and MRC5 cancer cell lines, respectively. Compound 25 was also cytotoxic to $\mathrm{KB}$ and MRC5 cells ( $\mathrm{IC}_{50}=13.9$ and $12.2 \mu \mathrm{M}$, respectively). Unfortunately compounds $\mathbf{2 3}$ and $\mathbf{2 4}$ were inactive $\left(\mathrm{IC}_{50}>\right.$ $30 \mu \mathrm{M}$ ) on all tested cancer cell lines (Mandavid et al., 2015). Colletotrichones A-C (26-28) were isolated from the endophytic fungus Colletotrichum sp.BS4, obtained from the leaves of the famous Chinese medicinal plant boxwood, Buxus sinica (Wang et al., 2016). Compound 26 showed remarkable antibacterial potencies against environmental bacteria in comparison to the standard antibiotics streptomycin and gentamicin. Compound 28 displayed bioactivity against E. coli. Compound 27a demonstrated the same potency as streptomycin against the clinically relevant bacterium $S$. aureus. None of the individual compounds showed in vitro cytotoxicity on a human acute monocytic leukemia cell line (THP-1) (Wang et al., 2016). Due to the discovery of the very effective compounds 26-28 which are related to the azaphilones group, the study suggested that more investigation should be done on the endophytemediated host chemical defense against pathogens. As the endophytic fungus was obtained from the leaves of B. sinica, the azaphilone compounds may provide an example of natural product-mediated chemical defense to the host plant species against different bacteria.

The endophytic fungus Nectria sp. HN001, which was obtained from the mangrove plant Sonneratia ovata collected from the South China Sea, delivered nectriacids A-C (2931) and 12-epicitreoisocoumarinol (32), along with three known compounds. Compounds (29-32) were tested against $\alpha$ glucosidase inhibitory activity by UV absorbance at $405 \mathrm{~nm}$. Compounds $\mathbf{3 0}$ and $\mathbf{3 1}$ showed potent inhibitory activity (Cui et al., 2016). Endomeketals A-B (33-34) were isolated from the endophytic fungus Endomelanconiopsis endophytica A326 harbored in Ficus hirta (Sun et al., 2016). E. endophytica was discovered as a new anamorph genus in the Botryosphaeriaceae. Unfortunately compounds $\mathbf{3 3}$ and $\mathbf{3 4}$ didn't display cytotoxic activity against 4 tumor cell lines, SF-268, MCF-7, NCIH460, and HepG-2. The endophytic fungus Mucor irregularis harbored in the medicinal plant Moringa stenopetala, collected in Cameroon, afforded the new cyclic heptapeptide unguisin $\mathrm{F}$ (35) (Akone et al., 2016). Compound 35 didn't show significant antimicrobial activity. The endophytic fungus Penicillium sp. R22 was isolated from the root of the medicinal plant Nerium indicum collected from Qinling Mountain, Shaanxi Province, China.

A new secondary metabolite named 5-hydroxy-8-methoxy4-phenylisoquinolin-1(2H)-one (36) was discovered from Penicillium sp. R22 together with other known isoquinoline alkaloid derivatives. Compound $\mathbf{3 6}$ displayed weak antibacterial activity (Ma et al., 2017). Unusual $\mathrm{C}_{25}$ steroids named as 
neocyclocitrinols E-G (37-39), together with 3 $\beta$-hydroxy-5,9epoxy-(22E,24R)-ergosta-7,22-dien-6-one (40) were isolated from the endophytic fungus Chaetomium sp. M453 obtained from the Chinese herbal medicine Huperzia serrate (Yu et al., 2017). To our knowledge all natural products have an essential function in their respective habitat and random screening may be the only way to discover this activity. That means when a natural compound doesn't exhibit antimicrobial or anticancer activities it perhaps has other biological applications, which should be discovered.

In conclusion, endophytic fungi have been found to be a major source of phytochemicals and numerous bioactive secondary metabolites as also reported by Machavariani and Terekhova (2014). Owing to the discovery of the abovementioned metabolites which were obtained from endophytic fungi, it can be assumed that endophytic fungi have very exciting possibilities to produce a plethora of novel bioactive natural products (Kusari et al., 2012). These findings highlight the importance of chemical communication strategies of endophytic fungi with their host plants and with other endophytic associations and their role in the activation of cryptic secondary metabolism pathways in endophytic fungi (Scherlach and Hertweck, 2009; Walsh and Fischbach, 2010). These lead to the varied biological diversity of endophytes, especially fungi, and their capability to produce bioactive molecules, which highlights a number of interesting research areas on endophytes.

\section{FUTURE PERSPECTIVES}

Until now little has been achieved worldwide in the research area of endophytic fungi and bacteria, and few strains have been isolated, implying that the opportunity to find promising

\section{REFERENCES}

Abdalla, M. A. (2016). Medicinal significance of naturally occurring cyclotetrapeptides. J. Nat. Med. 70, 708-720. doi: 10.1007/s11418-016-1001-5

Abdalla, M. A. (2017). Three new cyclotetrapeptides isolated from Streptomyces sp. 447. Nat. Prod. Res. 31, 1014-1021. doi: 10.1080/14786419.2016. 1263849

Abdalla, M. A., and Matasyoh, J. C. (2014). Endophytes as producers of peptides: an overview about the recently discovered peptides from endophytic microbes. Nat. Prod. Bioprospect. 4, 257-270. doi: 10.1007/s13659-014-0038-y

Adamu, M., Naidoo, V., and Eloff, J. N. (2012). Some southern African plant species used to treat helminth infections in ethnoveterinary medicine have excellent antifungal activities. BMC Complement. Altern. Med. 12:213. doi: 10.1186/1472-6882-12-213

Ahmad, I., and Beg, A. Z. (2001). Antimicrobial and phytochemical studies on 45 Indian medicinal plants against multi-drug resistant human pathogens. $J$. Ethnopharmacol. 74, 113-123. doi: 10.1016/S0378-8741(00)00335-4

Akone, S. H., Daletos, G., Lin, W., and Proksch, P. (2016). Unguisin F, a new cyclic peptide from the endophytic fungus Mucor irregularis. Z. Naturforsch. C 71, 15-19. doi: 10.1515/znc-2015-0137

Alain, K., and Querellou, J. (2009). Cultivating the uncultured: limits, advances and future challenges. Extremophiles 13, 583-594. doi: 10.1007/s00792-009-0261-3

Alho, C. J. (2008). Biodiversity of the Pantanal: response to seasonal flooding regime and to environmental degradation. Braz. J. Biol. 68, 957-966. doi: 10.1590/S1519-69842008000500005 strains and their novel natural products in different niches and ecosystems is huge. Plants growing in areas of great biodiversity have the highest potential for housing endophytes.

South Africa, which represents less than $1 \%$ of the world's land surface, possesses $8 \%$ of its plant species. It attracts the scientific community due to the rich plant biodiversity, as it contains over 20000 different species (Cherry, 2005). In the longer term, the unique diversity of South African plants serves as a great source for discovering the endophytic biodiversity, their secondary metabolites, and more about the interesting relationship between endophytes and their host plants. Since endophytes from South African medicinal plants have not been studied in any detail, there is a need to screen them for production of bioactive metabolites as they are often easily cultured and cultivated in the laboratory instead of collecting the plants and hence affecting the environment. Endophytes could also be responsible for the medicinal properties of the plants; in this regard interesting scientific scenarios will be discovered by studying their bioactivities as well as their secondary metabolites. This may lead to the isolation of new drug candidates, especially from those potential plants, as the endophytic compounds may be responsible for the entire activity.

\section{AUTHOR CONTRIBUTIONS}

MA conceptualized the idea, wrote, and edited the manuscript and LM provided input during preparation, edited, and submitted the manuscript.

\section{ACKNOWLEDGMENTS}

The University of Pretoria, South Africa is acknowledged for the senior postdoctoral fellowship to MA.
Amusan, O. O. G., Dlamini, P. S., Msonthi, J. D., and Makhubu, J. D. (2002). Some herbal medicines from Manzini Region, Swaziland. J. Ethnopharmacol. 79, 109-112. doi: 10.1016/S0378-8741(01)00381-6

Aremu, A. O., Ndhlala, A. R., Fawole, O. A., Light, M. E., Finnie, J. F., and Van Staden, J. (2010). In vitro pharmacological evaluation and phenolic content of ten South African medicinal plants used as anthelmintics. S. Afr. J. Bot. 76, 558-566. doi: 10.1016/j.sajb.2010.04.009

Aro, A. O., Dzoyem, J. P., Hlokwe, T. M., Madoroba, E., Eloff, J. N., and McGaw, L. J. (2015). Some South African Rubiaceae tree leaf extracts have antimycobacterial activity against pathogenic and non-pathogenic Mycobacterium species. Phyther. Res. 29, 1004-1010. doi: 10.1002/ptr.5338

Arora, P., Wani, Z. A., Nalli, Y., Ali, A., and Riyaz-Ul-Hassan, S. (2016). Antimicrobial potential of thiodiketopiperazine derivatives produced by Phoma sp., an endophyte of Glycyrrhiza glabra Linn. Microb. Ecol. 72, 802-812. doi: 10.1007/s00248-016-0805-x

Azevedo, J. L. (2014). "Endophytic fungi from Brazilian tropical hosts and their biotechnological applications," in Microbial Diversity and Biotechnology in Food Security, eds R. N. Kharwar, R. Upadhyay, N. Dubey, and R. Raghuwanshi (Springer), 17-22.

Bagla, V. P., McGaw, L. J., and Eloff,. J. N. (2012). The antiviral activity of six South African plants traditionally used against infections in ethnoveterinary medicine. Vet. Microbiol. 155, 198-206. doi: 10.1016/j.vetmic.2011.09.015

Bandara, W. M., Seneviratne, G., and Kulasooriya, S. A. (2006). Interactions among endophytic bacteria and fungi: effects and potentials. J. Biosci. 31, 645-650. doi: $10.1007 / \mathrm{BF} 02708417$ 
Bisi-Johnson, M. A., Obi, C. L., Kambizi, L., and Nkomo, M. (2010). A survey of indigenous herbal diarrhoeal remedies of O.R. Tambo district, Eastern Cape Province, South Africa. Afr. J. Biotechnol. 9, 1245-1254. doi: 10.5897/AJB09.1475

Bourdy, G., DeWalt, S. J., Chávez De Michel, L. R., Roca, A., Deharo, E., Muñoz, V., et al. (2000). Medicinal plants uses of the Tacana, an Amazonian Bolivian ethnic group. J. Ethnopharmacol. 70, 87-109. doi: 10.1016/S0378-8741(99)00158-0

Bradley, P. R. (1992). British Herbal Compendium, Vol. 1. Dorset: British Herbal Medicine Association.

Bruns, A., Cypionka, H., and Overmann, J. (2002). Cyclic AMP and acyl homoserine lactones increase the cultivation efficiency of heterotrophic bacteria from the central Baltic Sea. Appl. Environ. Microbiol. 68, 3978-3987. doi: 10.1128/AEM.68.8.3978-3987.2002

Canda, B. D., Oguntibeju, O. O., and Marnewick, J. L. (2014). Effects of consumption of rooibos (Aspalathus linearis) and a rooibos-derived commercial supplement on hepatic tissue injury by tert-butyl hydroperoxide in Wistar rats. Oxid. Med. Cell Longev. 2014:716832. doi: 10.1155/2014/716832

Canel, C., Moraes, R. M., Dayan, F. E., and Ferreira, D. (2000). Podophyllotoxin. Phytochemistry 54, 115-120. doi: 10.1016/S0031-9422(00)00094-7

Castillo, U., Myers, S., Browne, L., Strobel, G., Hess, W. M., Hanks, J., et al. (2005). Scanning electron microscopy of some endophytic streptomycetes in snakevine-Kennedia nigricans. Scanning 27, 305-311. doi: $10.1002 /$ sca.4950270606

Center for Disease Control and Prevention (2013). Achievements in Public Health, 1900-1999: Control of Infectious Diseases. Available online at: http://www. cdc.gov/mmwr/preview/mmwrhtml/mm4829a1.htm (Accessed Feburary 20, 2017).

Cherry, M. (2005). South Africa-Serious about Biodiversity Science. PLoS Biol. 3:e145. doi: 10.1371/journal.pbio.0030145

Choi, W.-Y., Rim, S.-O., Lee, J.-H., Lee, J.-M., Lee, I.-J., Cho, K.-J., et al. (2005). Isolation of gibberellins-producing fungi from the root of several Sesamum indicum plants. J. Microbiol. Biotechnol. 15, 22-28.

Clarkson, C., Maharaj, V. J., Crouch, N. R., Grace, O. M., Pillay, P., Matsabisa, M. G., et al. (2004). In vitro antiplasmodial activity of medicinal plants native to or naturalised in South Africa. J. Ethnopharmacol. 92, 177-191. doi: 10.1016/j.jep.2004.02.011

Compant, S., Saikkonen, K., Mitter, B., Andrea Campisano, A., and MercadoBlanco, J. (2016). Editorial special issue: soil, plants and endophytes. Plant Soil 405, 1-11. doi: 10.1007/s11104-016-2927-9

Connon, S. A., and Giovannoni, S. J. (2002). High-throughput methods for culturing microorganisms in very-low-nutrient media yield diverse new marine isolates. Appl. Environ. Microbiol. 68, 3878-3885. doi: 10.1128/AEM.68.8.3878-3885.2002

Croes, S., Weyens, N., Janssen, J., Vercampt, H., Colpaert, J. V., Carleer, R., et al. (2013). Bacterial communities associated with Brassica napus L. grown on trace element-contaminated and non-contaminated fields: a genotypic and phenotypic comparison. Microb. Biotechnol. 6, 371-384. doi: 10.1111/1751-7915.12057

Cui, H., Liu, Y., Nie, Y., Liu, Z., Chen, S., Zhang, Z., et al. (2016). Polyketides from the mangrove-derived endophytic fungus Nectria sp. HN001 and their $\alpha$-glucosidase inhibitory activity. Mar. Drugs 14:86. doi: 10.3390/md14050086

Damayanthi, Y., and Lown, J. W. (1998). Podophyllotoxins: current status and recent developments. Curr. Med. Chem. 5, 205-252. doi: 10.1002/chin.199834318

Davis, K. E., Joseph, S. J., and Janssen, P. H. (2005). Effects of growth medium, inoculum size, and incubation time on culturability and isolation of soil bacteria. Appl. Environ. Microbiol. 71, 826-834. doi: 10.1128/AEM.71.2.826-834.2005

Dey, P., and Chaudhuri, T. K. (2014). Pharmacological aspects of Nerium indicum Mill: a comprehensive review. Pharmacogn. Rev. 8, 156-162. doi: 10.4103/0973-7847.134250

Dzoyem, J. P., and Eloff, J. N. (2015). Anti-inflammatory, anticholinesterase and antioxidant activity of leaf extracts of twelve plants used traditionally to alleviate pain and inflammation in South Africa. J. Ethnopharmacol. 160, 194-201. doi: 10.1016/j.jep.2014.11.034

Eevers, N., Gielen, M., Sánchez-López, A., Jaspers, S., White, J. C., Vangronsveld, J., et al. (2015). Optimization of isolation and cultivation of bacterial endophytes through addition of plant extract to nutrient media. Microb. Biotechnol. 8, 707-715. doi: 10.1111/1751-7915.12291

El-Amrania, M., Ebadab, S. S., Gad, H. A., and Proksch, P. (2016). Pestalotiopamide E and pestalotiopin B from an endophytic fungus Aureobasidium pullulans isolated from Aloe vera leaves. Phytochem. Lett. 18, 95-98. doi: 10.1016/j.phytol.2016.09.006

Elisha, L. I., Dzoyem, J. P., Botha, F. S., and Eloff, J. N. (2016). The efficacy and safety of nine South African medicinal plants in controlling Bacillus anthracis Sterne vaccine strain. BMC Complement. Altern. Med. 16:5. doi: 10.1186/s12906-015-0980-1

Eyberger, A. L., Dondapati, R., and Porter, J. R. (2006). Endophyte fungal isolates from Podophyllum peltatum produce podophyllotoxin. J. Nat. Prod. 69, 1121-1124. doi: 10.1021/np060174f

Fair, R. J., and Tor, Y. (2014). Antibiotics and bacterial resistance in the $21 \mathrm{st}$ Century. Perspect. Med. Chem. 6, 25-64. doi: 10.4137/PMC.S14459

Fawole, O. A., Finnie, J. F., and Van Staden, J. (2009). Antimicrobial activity and mutagenic effects of twelve traditional medicinal plants used to treat ailments related to the gastro-intestinal tract in South Africa. S. Afr. J. Bot. 75, 356-362. doi: 10.1016/j.sajb.2008.11.002

Flores-Bustamante, Z. R., Rivera-Orduña, F. N., Martínez-Cárdenas, A., and Flores-Cotera, L. B. (2010). Microbial paclitaxel: advances and perspectives. J. Antibiot. 63, 460-467. doi: 10.1038/ja.2010.83

Fonseca-García, C., Coleman-Derr, D., Garrido, E., Visel, A., Tringe, S. G., and Partida-Martínez, L. P. (2016). The Cacti microbiome: interplay between habitat-filteringand host-specificity. Front. Microbiol. 12:150. doi: $10.3389 /$ fmicb. 2016.00150

Gagne-Bourque, F. (2011). The Isolation, Identification and Characterization of Endophytes of Switchgrass (Panicum virgatum L.), a Bioenergy Crop. M.Sc. thesis, McGill University, Montreal, QC.

Germishuizen, G., and Meyer, N. L. (eds.) (2003). Plants of Southern Africa: An Annotated Checklist. Pretoria: National Botanical Institute.

Gilani, A. H., Khan, A. U., Ghayur, M. N., Ali, S. F., and Herzig, J. W. (2006). Antispasmodic effects of Rooibos tea (Aspalathus linearis) is mediated predominantly through $\mathrm{K}^{+}$-channel activation. Basic Clin. Pharmacol. Toxicol. 99, 365-373. doi: 10.1111/j.1742-7843.2006.pto_507.x

Golinska, P., Wypij, M., Agarkar, G., Rathod, D., Dahm, H., and Rai, M. (2015). Endophytic actinobacteria of medicinal plants: diversity and bioactivity. Antonie Van Leeuwenhoek 108, 267-289. doi: 10.1007/s10482-015-0502-7

Gos, F. M. W. R., Savi, D. C., Shaaban, K. A., Thorson, J. S., Aluizio, R., Possiede, Y. M., et al. (2017). Antibacterial activity of endophytic actinomycetes isolated from the medicinal plant Vochysia divergens (Pantanal, Brazil). Front. Microbiol. 6:1642. doi: 10.3389/fmicb.2017.01642

Gunatilaka, A. A. (2006). Natural products from plant-associated microorganisms: distribution, structural diversity, bioactivity, and implications of their occurrence. J. Nat. Prod. 69, 505-526. doi: 10.1021/np058128n

Guo, B., Wang, Y., Sun, X., and Tang, K. (2008). Bioactive natural products from endophytes: a review. Appl. Biochem. Microbiol. 44, 136-142. doi: 10.1134/S0003683808020026

Hammerschmidt, L., Ola, A., Müller, W. E. G., Lin, W., Mándi, A., Kurtán, T., et al. (2015). Two new metabolites from the endophytic fungus Xylaria sp. isolated from the medicinal plant Curcuma xanthorrhiza. Tetrahedron Lett. 56, 1193-1197. doi: 10.1016/j.tetlet.2014.12.120

Hao, X., Jiao Pan, J., and Zhu, X. (2013). "Taxol producing fungi," in Natural Products, eds K. G. Ramawat and J. M. Merillon (Berlin; Heidelberg: Springer Verlag), 2797-2812.

Harvey, A. L., Young, L. C., Viljoen, A. M., and Gericke, N. P. (2011) Pharmacological actions of the South African medicinal and functional food plant Sceletium tortuosum and its principal alkaloids. J. Ethnopharmacol. 137, 1124-1129. doi: 10.1016/j.jep.2011.07.035

Harvey, W. H., and Sonder, O. W. (eds.) (1860,1862,1864). Flora Capensis, Vol. 1, 2 and 3. Dublin: Hodges-Smith.

Ho, Y. S., So, K. F., and Chang, R. C. (2011). Drug discovery from Chinese medicine against neurodegeneration in Alzheimer's and vascular dementia. Chinese Med. 6:15. doi: 10.1186/1749-8546-6-15

Hosseinzadeh, H., and Nassiri-Asl, M. (2015). Pharmacological effects of Glycyrrhiza spp. and its bioactive constituents: update and review. Phytother. Res. 29, 1868-1886. doi: 10.1002/ptr.5487 
Hsiang, Y. H., Hertzberg, R., Hecht, S., and Liu, L. F. (1985). Camptothecin induces protein-linked DNA breaks via mammalian DNA topoisomerase I. J. Biol. Chem. 260, 14873-14878.

Hurinanthan, V. (2013). Anti-HIV Activity of Selected South African Medicinal Plants. Ph.D. Thesis, Department of Biotechnology and Food Technology, Durban University of Technology, Durban,144.

Hurst, C. J. (2005). Divining the future of microbiology. ASM News 71, 262-263

Isaacs, T. (2008). A Brief History of the Wondrous Oleander Plant Part 3 of the Oleander Series. Natural news. Available online at: http://www.naturalnews. com/022949_Oleander_health_history.html\#

Iwalewa, E. O., McGaw, L. J., Naidoo, V., and Eloff, J. N. (2007). Inflammation: the foundation of diseases and disorders. A review of phytomedicines of South African origin used to treat pain and inflammatory conditions. Afr. J. Biotechnol. 6, 2868-2885. doi: 10.5897/AJB2007. 000-2457

Ji, Z. Q., Wu, W. J., Wang, M. A., and Gu, A. G. (2005). Identification of fungicidal compounds from endophytic fungi Fusarium proliferatum in Celastrus angulatus. J.Northwest Sci. Tech. Univ. Agric. For. 33, 61-64.

Jinfeng, E. C., Mohamad Rafi, M. I., Chai Hoon, K., Kok Lian, H., and Yoke Kqueen, C. (2017). Analysis of chemical constituents, antimicrobial and anticancer activities of dichloromethane extracts of Sordariomycetes sp. endophytic fungi isolated from Strobilanthes crispus. World J. Microbiol. Biotechnol. 33, 1-19. doi: 10.1007/s11274-016-2175-4

Jumpathong, J., Abdalla, M. A., Lumyong, S., and Laatsch, H. (2010). Stemphol galactoside, a new stemphol derivative isolated from the tropical endophytic fungus Gaeumannomyces amomi. Nat. Prod. Commun. 5, 567-570.

Kabongo-Kayoka, P. N., Eloff, J. N., Obi, C. L., and McGaw, L. J. (2016). Antimycobacterial activity and low cytotoxicity of leaf extracts of some African Anacardiaceae tree species. Phytother. Res. 30, 2001-2011. doi: $10.1002 /$ ptr.5706

Kacprzak, K. M. (2013). "Chemistry and biology of Cinchona alkaloids," in Natural Products Phytochemistry, Botany and Metabolism of Alkaloids, Phenolics and Terpenes, eds K. G. Ramawat and J.-M. Mérillon (Berlin; Heidelberg: Springer), 606-634.

Kametani, S., Kojima-Yuasa, A., Kikuzaki, H., Kennedy, D. O., Monzawa, M., and Matsui-Yuasa, I. (2007). Chemical constituents of Cape Aloe and their synergistic growth-inhibiting effect on Ehrlich ascites tumor cells. Biosci. Biotechnol. Biochem. 71, 1220-1229. doi: 10.1271/bbb.60659

Kamnev, A. A., Tugarova, A. V., Antonyuk, L. P., Tarantilis, P. A., Polissiou, M. G., and Gardiner, P. H. E. (2005). Effects of heavy metals on plantassociated rhizobacteria: comparison of endophytic and non-endophytic strains of Azospirillum brasilense. J. Trace Elem. Med. Biol. 19, 91-95. doi: 10.1016/j.jtemb.2005.03.002

Kamng'ona, A., Moore, J. P., Lindsey, G., and Brandt, W. (2011). Inhibition of HIV-1 and M-MLV reverse transcriptases by a major polyphenol (3,4,5 triO-galloylquinic acid) present in the leaves of the South African resurrection plant, Myrothamnus flabellifolia. J. Enzyme Inhib. Med. Chem. 26, 843-853. doi: 10.3109/14756366.2011.566220

Kawakami, M., Kobayashi, A., and Kator, K. (1993). Volatile constituents of Rooibos tea (Aspalathus linearis) as affected by extraction process. J. Agric. Food Chem. 41, 633-636. doi: 10.1021/jf00028a023

Kibiti, C. M. (2016). Evaluation of the Medicinal Potentials of Bulbine abyssinica A Rich in the Management of Diabetes Mellitus in the Eastern Cape, South Africa. Ph.D. thesis. University Of Fort Hare, South Africa.

Kuete, V. (2013). Medicinal Plant Research in Africa: Pharmacology and Chemistry. Elsevier Incorporated.

Kumar, A., Patil, D., Rajamohanan, P. R., and Absar Ahmad, A. (2013). Isolation, purification and characterization of vinblastine and vincristine from endophytic fungus Fusarium oxysporum isolated from Catharanthus roseus. PLoS ONE 8:e71805. doi: 10.1371/journal.pone.0071805

Kunoh, H. (2002). Endophytic actinomycetes: attractive biocontrol agents. J. Gen. Plant Pathol. 68, 249-252. doi: 10.1007/PL00013084

Kusari, S., Zühlke, S., and Spiteller, M. (2009). An endophytic fungus from Camptotheca acuminata that produces camptothecin and analogues. J. Nat. Prod. 72, 2-7. doi: 10.1021/np800455b

Kusari, S., Hertweck, C., and Spiteller, M. (2012). Chemical ecology of endophytic fungi: origins of secondary metabolites. Chem. Biol. 19, 792-798. doi: 10.1016/j.chembiol.2012.06.004
Kusari, S., Singh, S., and Jayabaskaran, C. (2014). Rethinking production of Taxol (paclitaxel) using endophyte biotechnology. Trends Biotechnol. 32, 304-311. doi: 10.1016/j.tibtech.2014.03.011

Lewis, K., Epstein, S., D’Onofrio, A., and Ling, L. L. (2010). Uncultured microorganisms as a source of secondary metabolites. J. Antibiot. 63, 468-476. doi: $10.1038 /$ ja.2010.87

Li, J., Zhao, G. Z., Chen, H. H., Wang, H. B., Qin, S., Zhu, W. Y., et al. (2008). Antitumour and antimicrobial activities of endophytic streptomycetes from pharmaceutical plants in rainforest. Lett. App. Microbiol. 47, 574-580. doi: 10.1111/j.1472-765X.2008.02470.x

Li, Q. Y., Zu, Y. G., Shi, R. Z., and Yao, L. P. (2006). Review camptothecin: current perspectives. Curr. Med. Chem. 13, 2021-2039. doi: 10.2174/092986706777585004

Liaqat, F., and Eltem, R. (2016). Identification and characterization of endophytic bacteria isolated from in vitro cultures of peach and pear rootstocks. 3Biotech 6:120. doi: 10.1007/s13205-016-0442-6

Lin, J., Puckree, T., and Mvelase, T. P. (2002). Anti-diarrhoeal evaluation of some medicinal plants used by Zulu traditional healers. J. Ethnopharmacol. 79, 53-56. doi: 10.1016/S0378-8741(01)00353-1

Liu, L. F., Desai, S. D., Li, T. K., Mao, Y., Sun, M., and Sim, S. P. (2006). Mechanism of action of camptothecin. Ann. N. Y. Acad. Sci. 922, 1-10. doi: 10.1111/j.1749-6632.2000.tb07020.x

Liu, S., Dai, H., Makhloufi, G., Heering, C., Janiak, C., Hartmann, R., et al. (2016). Cytotoxic 14-membered macrolides from a mangrove-derived endophytic fungus, Pestalotiopsis microspore. J. Nat. Prod. 79, 2332-2340. doi: 10.1021/acs.jnatprod.6b00473

Loots, D. T., Van der Westhuizen, F. H., and Botes, L. (2007). Aloe ferox leaf gel phytochemical content, antioxidant capacity, and possible health benefits. J. Agric. Food Chem. 55, 6891-6896. doi: 10.1021/jf071110t

Ma, Y.-M., Qiao, K., Kong, Y., Li, M.-Y., Guo, L.-X., Miao, Z., et al. (2017). A new isoquinolone alkaloid from an endophytic fungus R22 of Nerium indicum. Nat. Prod. Res. 31, 951-958. doi: 10.1080/14786419.2016.1258556

Mabona, U., Viljoen, A., Shikanga, E., Andrew Marstond, A., and Van Vuuren, S. (2013). Antimicrobial activity of southern African medicinal plants with dermatological relevance: from an ethnopharmacological screening approach, to combination studies and the isolation of a bioactive compound. J. Ethnopharmacol. 148, 45-55. doi: 10.1016/j.jep.2013. 03.056

Machavariani, N. G., and Terekhova, L. P. (2014). Biologically active compounds produced by microbial endophytes. Antibiot. Khimioter. 59, 26-33.

Maehara, S., Simanjuntak, P., Kitamura, C., Ohashi, K., and Shibuy, H. (2011). Cinchona alkaloids are also produced by an endophytic filamentous fungus living in cinchona plant. Chem. Pharm. Bull. 59, 1073-1074. doi: $10.1248 / \mathrm{cpb} .59 .1073$

Mandavid, H., Rodrigues, A. M. S., Laila, S., Espindola, L. S., Eparvier, V., and Stien, D. (2015). Secondary metabolites isolated from the Amazonian endophytic fungus Diaporthe sp. SNB-GSS10. J. Nat. Prod. 78, 1735-1739. doi: 10.1021/np501029s

Maphosa, V., and Masika, P. (2012). In vivo validation of Aloe ferox (Mill). Elephantorrhiza elephantina Bruch. Skeels. and Leonotis leonurus (L) R. BR as potential anthelminthics and antiprotozoals against mixed infections of gastrointestinal nematodes in goats. Parasitol. Res. 110, 103-108. doi: $10.1007 / \mathrm{s} 00436-011-2455-8$

Maphosa, V., Masika, P. J., Bizimenyera, E. S., and Eloff, J. N. (2010). In-vitro anthelminthic activity of crude aqueous extracts of Aloe ferox, Leonotis leonurus and Elephantorrhiza elephantina against Haemonchus contortus. Trop. Anim. Health Prod. 42, 301-307. doi: 10.1007/s11250-009-9421-9

Mathabe, M. C., Nikolova, R. V., Lall, N., and Nyazema, N. Z. (2006). Antibacterial activities of medicinal plants used for the treatment of diarrhoea in Limpopo Province, South Africa. J. Ethnopharmacol. 105, 286-293. doi: 10.1016/j.jep.2006.01.029

McGaw, L. J., Lall, N., Meyer, J. J. M., and Eloff, J. N. (2008). The potential of South African plants against Mycobacterium infections. J. Ethnopharmacol. 119, 482-500. doi: 10.1016/j.jep.2008.08.022

Mehrbod, P., Abdalla, M. A., Njoya, E. M., Ahmed, A. S., Fotouhi, F., Farahmand, B., et al. (2018). South African medicinal plant extracts active against influenza A virus. BMC Complement. Altern. Med. 18:112. doi: $10.1186 /$ s12906-018-2184-y 
Mekhail, T. M., and Markman, M. (2002). Paclitaxel in cancer therapy. Expert Opin. Pharmacother. 3, 755-766. doi: 10.1517/14656566.3.6.755

Mekonnen, Y., and Gessesse, A. (1998). Documentation on the uses of Moringa stenopetala and its possible antileishmanial and antifertility effects. SINET: Ethiop. J. Sci. 21, 287-295.

Miller, K. I., Qing, C., Sze, D. M. Y., and Neilan, B. A. (2012). Investigation of the biosynthetic potential of endophytes in traditional Chinese anticancer herbs. PLOS ONE 7:e35953. doi: 10.1371/journal.pone. 0035953

Moolla, A. (2005). A Phytochemical and Pharmacological Investigation of Indigenous Agathosma Species. M.Sc. Thesis in Pharmacy, University of the Witwatersrand, Johannesburg, 321

Motlhatlego, K. E., Njoya, E. M., Abdalla, M. A., Eloff, J. N., and McGaw, L. J. (2018). The potential use of leaf extracts of two Newtonia (Fabaceae) species to treat diarrhoea. S. Afr. J. Bot. 116, 25-33. doi: 10.1016/j.sajb.2018.02.395

Moudi, M., Go, R., Yong Seok Yien, C., and Nazre, M. (2013). Vinca alkaloids. Int. J. Prev. Med. 4, 1231-1235.

Mthethwa, N. S., Oyedeji, B. A., Obi, L. C., and Aiyegoro, O. A. (2014). Anti-staphylococcal, anti-HIV and cytotoxicity studies of four South African medicinal plants and isolation of bioactive compounds from Cassine transvaalensis (Burtt Davy) Codd. BMC Complement. Altern. Med. 14:512. doi: $10.1186 / 1472-6882-14-512$

Ni, Z. W., Li, G. H., Zhao, P. J., and Shen, Y. M. (2008). Antimicrobial components of the endophytic fungal strain Chaetomium globosum, from Mantenus hookeri. Nat. Prod. Res. Dev. 20, 33-36.

Nichols, D., Lewis, K., Orjala, J., Mo, S., Ortenberg, R., O'Connor, P., et al. (2008). Short peptide induces an 'uncultivable' microorganism to grow in vitro. Appl. Environ. Microbiol. 74, 4889-4897. doi: 10.1128/AEM.00393-08

Nyila, M. A., Leonard, C. M., Hussein, A. A., and Lall, N. (2012). Activity of South African medicinal plants against Listeria monocytogenes biofilms, and isolation of active compounds from Acacia karroo. S. Afr. J. Bot. 78, 220-227. doi: 10.1016/j.sajb.2011.09.001

Okem, A., Finnie, J. F., and Van Staden, J. (2012). Pharmacological, genotoxic and phytochemical properties of selected South African medicinal plants used in treating stomach-related ailments. J. Ethnopharmacol. 139, 712-720. doi: 10.1016/j.jep.2011.11.034

Otang, W. M., Grierson, D. S., and Ndip, R. N. (2012). Ethnobotanical survey of medicinal plants used in the management of opportunistic fungal infections in HIV/AIDS patients in the Amathole District of the Eastern Cape Province, South Africa. J. Med. Plants Res. 6, 2071-2080.

Oyedemi, S. O., Bradley, G., and Afolayan, A. J. (2009). Ethnobotanical survey of medicinal plants used for the management of diabetes mellitus in the Nkonkobe municipality of South Africa. J. Med. Plants Res. 3, 1040-1044.

Pavlo, A., Leonid, O., Iryna, Z., Natalia, K., and Maria, P. A. (2011). Endophytic bacteria enhancing growth and disease resistance of potato (Solanum tuberosum L.). Biol. Control 56, 43-49. doi: 10.1016/j.biocontrol.2010.09.014

Pimentel, M. R., Molina, G., Dionísio, A. P., Maróstica Junior, M. R., and Pastore, G. M. (2011). The use of endophytes to obtain bioactive compounds and their application in biotransformation. Biotechnol. Res. Int. 2011:576286. doi: $10.4061 / 2011 / 576286$

Ramadwa, T. E., Elgorashi, E. E., McGaw, L. J., Ahmed, A. S., and Eloff, J. N. (2017). Antimicrobial, anti-inflammatory activity and cytotoxicity of Funtumia africana leaf extracts, fractions and the isolated methyl ursolate. S. Afr. J. Bot. 108, 126-131. doi: 10.1016/j.sajb.2016.10.019

Ramos-Garza, J., Rodríguez-Tovar, A. V., Flores-Cotera, L. B., RiveraOrduña, F. N., Vásquez-Murrieta, M. S., Ponce-Mendoza, A., et al. (2015). Diversity of fungal endophytes from the medicinal plant Dendropanax arboreus in a protected area of Mexico. Ann. Microbiol. 66, 991-1002. doi: 10.1007/s13213-015-1184-0

Rodriguez, R. J., White, J. F. Jr., Arnold, A. E., and Redman, R. S. (2009). Fungal endophytes: diversity and functional role. New Phytol. 182, 314-330. doi: $10.1111 /$ j.1469-8137.2009.02773.x

Roza, O., Lovász, N., Zupkó, I., Hohmann, J., and Csupor, D. (2013). Sympathomimetic activity of a Hoodia gordonii product: a possible mechanism of cardiovascular side effects. BioMed Res. Int. 2013:171059. doi: $10.1155 / 2013 / 171059$

Saeed, M. E. M., Meyer, M., Hussein, A., and Efferth, T. (2016). Cytotoxicity of South-African medicinal plants towards sensitive and multidrug-resistant cancer cells. J. Ethnopharmacol. 186, 209-223. doi: 10.1016/j.jep.2016.04.005
Saeed, N., Khan, M. R., and Shabbir, M. (2012). Antioxidant activity, total phenolic and total flavonoid contents of whole plant extracts Torilis leptophylla L. BMC Complement. Altern. Med. 12:221. doi: 10.1186/1472-6882-12-221

Schardl, C. L. (2001). Epichloe festucae and related mutualistic symbionts of grasses. Fungal Genet. Biol. 33, 69-82. doi: 10.1006/fgbi.2001.1275

Scherlach, K., and Hertweck, C. (2009). Triggering cryptic natural product biosynthesis in microorganisms. Org. Biomol. Chem. 7, 1753-1760. doi: $10.1039 / \mathrm{b} 821578 \mathrm{~b}$

Schneider, P., Misiek, M., and Hoffmeister, D. (2008). In vivo and in vitro production options for fungal secondary metabolites. Mol. Pharm. 5, 234-242. doi: $10.1021 / \mathrm{mp} 7001544$

Schoch, C. L., Seifert, K. A., Huhndorf, S., Robert, V., Spouge, J. L., Levesque, C. A., et al. (2012). Nuclear ribosomal internal transcribed spacer (ITS) region as a universal DNA barcode marker for fungi. Proc. Nat. Acad. Sci. U.S.A. 109, 6241-6246. doi: 10.1073/pnas.1117018109

Sebastianes, F. L., Cabelo, N., El Aouade, N., Valente, A. M., Lacava, P. T., Azevedo, J. L., et al. (2012). 3-Hydroxypropionic acid as an antibacterial agent from endophytic fungi Diaporthe phaseolorum. Curr. Microbiol. 65, 622-632. doi: 10.1007/s00284-012-0206-4

Semenya, S. S., and Maroyi, A. (2012). Medicinal plants used by the Bapedi traditional healers to treat diarrhoea in the Limpopo Province, South Africa. J. Ethnopharmacol. 144, 395-401. doi: 10.1016/j.jep. 2012.027

Setzer, W. N., Gu, X., Wells, E. B., Setzer, M. C., and Moriarity, D. M. (2000). Synthesis and cytotoxic activity of a series of diacetylenic compounds related to falcarindiol. Chem. Pharm. Bull. 48, 1776-1777. doi: 10.1248/cpb.48.1776

Sharma, R., and Lall, N. (2014). Antibacterial, antioxidant activities and cytotoxicity of plants against Propionibacterium acnes. S. Afr. J. Sci. 110, 1-8. doi: 10.1590/sajs.2014/20130293

Soliman, S. S. M., Greenwood, J. S., Bombarely, A., Mueller, L. A., Tsao, R., Mosser, D. D., et al. (2015). An endophyte constructs fungicidecontaining extracellular barriers for its host plant. Curr. Biol. 25, 2570-2576. doi: 10.1016/j.cub.2015.08.027

Song, C. E. (2009). An Overview of Cinchona Alkaloids in Chemistry. Cinchona Alkaloids in Synthesis and Catalysis, Ligands, Immobilization and Organocatalysis. Weinheim: WILEY-VCH Verlag GmbH and Co; KGaA.

Souza, A. Q. L., Souza, A. D. L., Astolfi-Filho, S., Belém-Pinheiro, L., Sarkis, M. M., and Pereira, J. O. (2004). Atividade antimicrobiana dse fungos endofíticos isolados de plantas tóxicas da Amazônia, Paulicorea longiflora and Strychnus cogens. Acta Amazônica 34, 185-195. doi: 10.1590/S0044-59672004000200006

Stone, J. K., White, J. F. Jr., and Polishook, J. D. (2004). "Endophytic fungi," in Measuring and Monitoring Biodiversity of Fungi. Inventory and Monitoring Methods, eds G. Mueller, G. Bills, and M. Foster (Boston, MA: Elsevier Academic Press), 241-270.

Strobel, G. (2003). Endophytes as sources of bioactive products. Microb. Infect. 5, 535-544. doi: 10.1016/S1286-4579(03)00073-X

Strobel, G., and Daisy, B. (2003). Bioprospecting for microbial endophytes and their natural products. Microbiol. Mol. Biol. Rev. 67, 491-502. doi: 10.1128/MMBR.67.4.491-502.2003

Sun, Z.-H., Li, H.-H., Liang, F.-L., Chen, Y.-C., Liu, H.-X., Li, S.N., et al. (2016). Two new secondary metabolites from the endophytic fungus Endomelanconiopsis endophytica. Molecules 21:943. doi: $10.3390 /$ molecules 21070943

Talbot, N. J. (2015). Plant immunity: a little help from fungal friends. Curr. Biol. 25, R1074-R1076. doi: 10.1016/j.cub.2015.09.068

Useful Tropical Plants Database (2014). Useful Tropical Plants Database 2014 by Ken Fern, Web Interface by Ajna Fern With Help From Richard Morris. Available online at: http://tropical.theferns.info., Last update on 2017-01-08 (Accessed Feburary 21, 2017)

Van Vuuren, S. (2008). A review: antimicrobial activity of South African medicinal plants. J. Ethnopharmacol. 119, 462-472. doi: 10.1016/j.jep.2008.05.038

Van Vuuren, S. F., Nkwanyana, M. N., and de Wet, H. (2015). Antimicrobial evaluation of plants used for the treatment of diarrhoea in a rural community in northern Maputaland, KwaZulu-Natal, South Africa. BMC Complement. Alter. Med. 15:53. doi: 10.1186/s12906-015-0570-2

Van Wyk, B.-E. (2011). The potential of South African plants in the development of new medicinal products. S. Afr. J. Bot. 77, 812-829. doi: 10.1016/j.sajb.2011.08.011 
Van Wyk, B.-E., van Oudtshoorn, B., and Gericke, N. (2009). Medicinal Plants of South Africa, 2nd Edn. Pretoria: Briza Publications.

Walsh, C. T., and Fischbach, M. A. (2010). Natural products version 2.0: connecting genes to molecules. J. Am. Chem. Soc. 132, 2469-2493. doi: $10.1021 / \mathrm{ja} 909118 \mathrm{a}$

Wang, W.-X., Kusari, S., Laatsch, H., Golz, C., Kusari, P., Strohmann, C., et al. (2016). Antibacterial azaphilones from an endophytic fungus, Colletotrichum sp. BS4. J. Nat. Prod. 79, 704-710. doi: 10.1021/acs.jnatprod.5b00436

Warhurst, D. C., Craig, J. C., Adagu, I. S., Meyer, D. J., and Lee, S. Y. (2003). The relationship of physico-chemical properties and structure to the differential antiplasmodial activity of the cinchona alkaloids. Malaria J. 2:26. doi: $10.1186 / 1475-2875-2-26$

Worldmark Encyclopedia of the Nations (2007). Band 1, Timothy L. Gall, Gale Group. Thomson Gale, 2007. Michigan: University of Michigan.

Ying-Qian, L., Wen-Qun, L., Morris-Natschke, S. L., Qian, K., Yang, L., Zhu, G.-X., et al. (2015). Perspectives on biologically active camptothecin derivatives. Med. Res. Rev. 35, 753-789. doi: 10.1002/med.21342

Yu, F.-X., Li, Z., Chen, Y., Yang, Y.-H., Li, G.-H., and Zhao, P.-J. (2017). Four new steroids from the endophytic fungus Chaetomium sp. M453 derived of Chinese Herbal Medicine Huperzia serrata. Fitoterapia 117, 41-46. doi: $10.1016 /$ j.fitote.2016.12.012
Yu, H., Zhang, L., Li, L., Zheng, C., Guo, L., Li, W., et al. (2010). Recent developments and future prospects of antimicrobial metabolites produced by endophytes. Microbiol. Res. 165, 437-449. doi: 10.1016/j.micres.2009. 11.009

Zhang, H. W., Song, Y. C., and Tan, R. X. (2006). Biology and chemistry of endophytes. Nat. Prod. Rep. 23, 753-771. doi: 10.1039/b609472b

Zhang, N., Zhang, C., Xiao, X., Zhang, Q., and Huang, B. (2016). New cytotoxic compounds of endophytic fungus Alternaria sp. isolated from Broussonetia papyrifera (L.) Vent. Fitoterapia 110, 173-180. doi: 10.1016/j.fitote.2016. 03.014

Conflict of Interest Statement: The authors declare that the research was conducted in the absence of any commercial or financial relationships that could be construed as a potential conflict of interest.

Copyright $\odot 2018$ Abdalla and McGaw. This is an open-access article distributed under the terms of the Creative Commons Attribution License (CC BY). The use, distribution or reproduction in other forums is permitted, provided the original author(s) and the copyright owner are credited and that the original publication in this journal is cited, in accordance with accepted academic practice. No use, distribution or reproduction is permitted which does not comply with these terms. 